\title{
Importance of pre-school science education
}

\author{
Sibel Demir Kaçan ${ }^{1 \mathrm{a}}$, and Dilek Çelikler ${ }^{1}$ \\ ${ }^{1}$ Department of Science Education, Faculty of Education, Ondokuz Mayıs University, Samsun, \\ Turkey
}

\begin{abstract}
Considering this aspect of the study, the objective of the study is determining the importance of science education in pre-school period. In this research, two open-ended questions were asked to the prospective teachers. In these questions, the focus was the importance of science education in the pre-school period for children and teachers. These two open-ended questions were developed and presented by two researchers, who are experts in their fields. The research was conducted with 4th year prospective pre-school students, who study at the pre-school teaching department of a university in Karadeniz region. For that purpose, 40 prospective pre-school teachers participated in the study. The data retrieved from the study were analyzed through content analysis. The results of the study provided various answers from the prospective teachers on the importance of science education both for children and themselves.
\end{abstract}

Keywords: Pre-school education, Science education, Prospective teacher

\section{Introduction}

Science education is a process that begins when children start to discover their surroundings. Therefore, it is important to provide children with a qualified science education starting from pre-school period. Our perceptions may vary throughout the time spent between our birth and puberty, furthermore; different objects, events, and people may draw our attention. As of the first month, a baby starts to realize and recognize its surroundings while its sense of curiosity increases day by day. This sense of curiosity may continue until the baby becomes an adult. However, due to outer factors, this motive, which is much more intense in the pre-school and early-childhood period, may not regarded as important or may be repressed. Some family members or teachers may behave in a manner that could prevent the development of child's sense of curiosity. Such behaviors may be performed intentionally or unintentionally. Moreover, during this process, children work towards completing their cognitive, affective, and characteristic development. Therefore, the sense of curiosity is a motive that should be developed and is quite significant for the development of children of this age. Children in pre-school age ask many questions about their surroundings and seek for answers to satisfy their curiosity. Especially the children,

\footnotetext{
${ }^{\text {a }}$ Corresponding author: sibelfe@hotmail.com
} 
who ask various questions and receive answers about their science-related surroundings, grow more interest in science and start to ask more questions about such subjects. This situation is of great importance for raising inquisitive and interrogating individuals. Raising individuals, who grow interest in science in pre-school period, ask questions, research, and produce ideas, will increase their motivation in science and enable them to look at events from different perspectives.

Children do not only obtain scientific, technological, and practical knowledge through formal education, but also through informal education. These everyday-life contexts can also be used in developing scientific knowledge at school, by means of extracurricular activities [1]. For that reason, pre-school period is very important for science education and this process should be an effective one. This also highlights the need to raise prospective pre-school teachers in a more precise manner.

In order for an adult to become a competent person, certain types of awareness must be developed at an early age. This awareness sometimes occurs in the routine course of life, whereas; some other types of it occur in a disciplinary learning process. Thus, early childhood and pre-school phase are of significance for this disciplinary approach. During the pre-school phase, children form the basis for their adulthood. The stronger this basis is, the more well-equipped the person will be as they older and integrate into the society. Preschool era is not only important for the overall development of an individual, but also for the development of different abilities. The education received in the preschool era is important for children to have the perspective of a musician, athlete, actor/actress or scientist. Therefore, this era is of high significance in terms of raising an individual, who is in peace with nature, can live and see science as a part of life. This pre-school era is when the child questions and reflects his/her sense of wonder the most. Indeed, sense of wonder is quite effective for improvement and fundamentals of science. A small sense of wonder is the most significant step for a new and big discovery. For that reason, it is of utmost importance that a child does not lose his/her sense of wonder and keep questioning and seeking answers to certain questions. This young individual, who poses questions to his/her family and teacher, actually executes the most fundamental activity of a scientist. A scientist conducts this questioning in a more disciplinary manner, whereas; a child conducts this randomly. These questions, which may seem "minor, basic, non-sense" to some, are in fact indicators of a questioning and creative approach. That's why these questions of children should not be randomly answered, instead their questions should be valued as much as possible and they should be given logical explanations. Scientists believe that the best way to learn science is learning by doing. During this era children need to ask questions, to research, to examine, and to learn implementing trial and problem solving skills [2].

The quality of the science education delivered at the pre-school era is important. It is believed that children, who already naturally have a sense of wonder during this era, must frequently encounter science-related situations and a certain discipline. Indeed, the way a child is raised during this era reflects the prospective society, therefore, children's perception of a scientist and science, their scientific process skills as well as the development of their creativity skills and scientific creativity skills must be taken into account [3]. In that context, the education of prospective pre-school teachers must be highlighted. Prospective pre-school teachers must be able to transfer science knowledge into children and must structure this processes in a well-equipped manner. For that reason it is believed that prospective pre-school teachers must be well-trained in terms of their science knowledge. Raising prospective pre-school teachers with good science qualifications will significantly affect the interest of children in science and research. 
Considering this aspect of the study, the objective of the study is determining the importance of science education in pre-school period.

\section{Method}

\subsection{Participants}

The research was conducted with 4th year prospective pre-school students, who study at the pre-school teaching department of a university in Karadeniz region. For that purpose, 40 prospective pre-school teachers participated in the study.

\subsection{Procedure}

In this research, two open-ended questions were asked to the prospective teachers. In these questions, the focus was the importance of science education in the pre-school period for children and teachers. These two open-ended questions were developed and presented by two researchers, who are experts in their fields.

The pattern of the study is "'case study'. Case study can be defined as a system, in which one or multiple cases, environments, programs, social groups or other interdependent systems are thoroughly examined. The data retrieved from the study were analyzed through content analysis. The content analysis is the ability to elaborately examine information through certain codings and categories. The data collected from the open-ended questions were evaluated through content analysis. According to the researchers, content analysis is a systematical and iterable technique, through which certain words of a text can be summarized in smaller content categories via codings [4].

\section{Findings}

The data obtained from the research are displayed in two tables. Table 1 demonstrates themes related to importance of pre-school science education for children, whereas; Table 2 displays themes relevant to the significance of science education for prospective pre-school teachers.

As demonstrated in Table 1, "mental skills, hand skills, environmental awareness, science-literacy, being a basis for vocational training, problem and observation skills" come to the front for the significance of science education for children.

Examining the themes relevant to the significance of science education for prospective pre-school teachers as displayed in Table 2, concepts such as "environmental awareness, sense of wonder, questioning, everyday-life, teacher-student competency" come to the front. 
Table 1. Themes related to importance of pre-school science education for children

\begin{tabular}{cc}
\hline Themes & f \\
\hline Using mental skills & 20 \\
\hline Using hand skills & 17 \\
\hline Environmental awareness & 17 \\
\hline Problem solving skills & 12 \\
\hline Being a basis for vocational training & 12 \\
\hline Observation skills & 10 \\
\hline Being science-literate & 10 \\
\hline Sense of wonder & 9 \\
\hline Social skills & 9 \\
\hline Experiment & 9 \\
\hline Questioning skills & 7 \\
\hline Research & 6 \\
\hline Observation & 6 \\
\hline Understanding the world & 6 \\
\hline Discovery & 6 \\
\hline Interpreting everyday-life & 5 \\
\hline Creating cause and effect relationship & 5 \\
\hline Examination & 4 \\
\hline Having knowledge & 4 \\
\hline Being interested in science & 4 \\
\hline Promoting to ask questions & 4 \\
\hline Enabling success & 4 \\
\hline Others... & \\
\hline
\end{tabular}

Table 2. Themes relevant to the significance of science education for prospective pre-school teachers.

\begin{tabular}{cc}
\hline Themes & f \\
\hline Environmental awareness & 17 \\
\hline Sense of wonder & 13 \\
\hline Questioning & 12 \\
\hline Every day-life & 8 \\
\hline Observation & 7 \\
\hline Teacher sufficient-student sufficient & 6 \\
\hline Learning by doing and experiencing & 5 \\
\hline Mental skills & 5 \\
\hline Understanding the world & 5 \\
\hline Survey & 5 \\
\hline Experimental & 5 \\
\hline Hand skills & 4 \\
\hline Activity & 4 \\
\hline Entertainment & 4 \\
\hline Being a guide & 3 \\
\hline Having knowledge & 3 \\
\hline Paying attention to interests and needs & 3 \\
\hline In selecting a profession & 3 \\
\hline Using a convenient method or technique & 3 \\
\hline Knowing how to transfer & 3 \\
\hline Motor skills & 3 \\
\hline Paying attention to cognitive development & 3 \\
\hline
\end{tabular}




\section{Discussion and conclusion}

Since children are curious and interested in research and asking questioning during the preschool era, they learn more easily through learning by doing and experiencing. The science education delivered at the pre-school phase must not be based on transferring science knowledge, but on providing environments, where children can satisfy their sense of wonder, be promoted to discover, research, examine, observe, assume, and make conclusions [5].

The results of the study suggest that prospective pre-school teachers attach importance to science education not only for themselves, but also for the children they will raise. Likewise, in a study carried out by a researcher, it is stated that teachers must provide children with convenient learning opportunities and environments, where children can research, satisfy their sense of wonder, see the cause-effect relationship, assert their ideas, and make assumptions by using their senses [6]. The same researcher also argues that preschool teacher's ability to prepare such environments depends on how well the pre-school teacher knows the nature of science and technology and the relationship between the society and environment.

The prospective teachers evaluated the importance of science education from their own perspective and stated that if they are sufficient enough, so will be the children. Moreover, they stressed on environmental awareness, science-literacy, and problem solving skills from the perspective of children. Indeed, in the study conducted by the researchers, it was found out that the majority of the pre-school teachers were not able to plan and execute science and nature activities at the desired quality, were unable to develop original materials, did not know about the effective teaching methods used in activities and did not use such teaching methods [7].

There exists many studies on the importance of science education in pre-school phase $[7,11]$. The results of the study provided various answers from the prospective teachers on the importance of science education both for children and themselves Within that context, this study tries to shed light on the importance of the learning process of prospective preschool teachers, especially for science education as well as to take a step towards enabling others to conduct new studies in future.

\section{References}

1. Şahin, F. Okul öncesinde fen kavramları ve öğretimi. F. Şahin (Ed.) içinde, Okul öncesi dönemde fen eğitimi (p.85-108), Ankara: Hedef CS Yayıncılık, 3.Baskı, (2016).

2. Uyanık Balat, G. Fen nedir ve çocuklar feni nasıl öğrenir? B. Akman, G. Uyanık Balat, \& T. Güler Yıldız (Ed.) içinde, Okul öncesi dönemde fen eğitimi (p.1-17). Ankara: Pegem Akademi. 4.Bask1, (2014).

3. Demir, S. Okul öncesi dönemde bilim anlayışı ve düşünme becerilerinin geliştirilmesi. F. Şahin (Ed.) içinde, Okul öncesi dönemde fen eğitimi (p.25-60). Ankara: Hedef CS Yayınc1lık, 3.Bask1, (2016).

4. Büyüköztürk, Ş., Kılıç Çakmak, E., Akgün, Ö. E., Karadeniz, Ş. \& Demirel, F. Bilimsel araştırma yöntemleri. Ankara: Pegem Akademi, (2008).

5. Ünal, M., \& Akman, B. Early childhood teachers' attidutes towards science teaching. H.Ü. Eğitim Fakültesi Dergisi, 30, 251-257, (2006).

6. Çınar, S. Okul öncesi öğretmenlerinin fen-teknoloji-toplum-çevre hakkındaki görüssleri. Journal of Research in Education and Teaching, 2(1), 349-363, (2013), ISSN: 2146-9199.

7. Ayvac1, H. Ş., Devecioğlu, Y. \& Yiğit, N. Okul öncesi öğretmenlerinin fen ve doğa etkinliklerindeki yeterliliklerinin belirlenmesi. V. Ulusal Fen Bilimleri ve Matematik 
Eğitimi Kongresi, Orta Doğu Teknik University, Ankara. http://www.fedu.metu.edu.tr/ufbmek5/bkitabi/PDF/OgretmenYtistirme/Bildiri/t277d.p df. (2002).

8. Büyüktaşkapu, S. Montessori yaklaşımı ve okul öncesinde fen eğitimi. Tubav Bilim Dergisi 5(3), 19-25, (2012).

9. Onur, A., Çağlar, A., \& Salman, M. Evaluation of waste paper and improvement of environmental awareness for 5 years old preschool children. 24(5), Kastamonu Eğitim Dergisi, 2457-2468, (2016).

10. Ayvac1, H. Ş., \& Yurt, Ö. Çocuk ve bilim eğitimi. Çocuk ve Medeniyet, 1, 15-28, (2016).

11. Karamustafaoğlu, S., \& Kandaz, U. Using teaching methods in the science activities and difficulties encountered in pre-school education. GÜ, Gazi Eğitim Fakültesi Dergisi, 26(1), 65-81, (2006). 